\title{
The effects of creatine supplementation with and without an Extract of Artemisia dracunculus on resistance training adaptations: preliminary findings
}

\author{
Adam G Parker $^{1 *}$, Taylor Steele ${ }^{1}$, Ralf Jäger ${ }^{2}$, Martin Purpura², Allyn G Byars ${ }^{1}$ \\ From International Society of Sports Nutrition: 10th Annual ISSN Conference and Expo \\ Colorado Springs, CO, USA. 14-15 June 2013
}

\section{Background}

Co-ingesting creatine $(5 \mathrm{~g})$ with large amounts of glucose (e.g., $95 \mathrm{~g}$ ) has been shown to enhance creatine and carbohydrate storage in muscle. It has been speculated that creatine transport is mediated in part by glucose and insulin. The increases in creatine retention are accompanied by an undesired caloric load and as a result, additional research has been undertaken to assess the effect of co-ingesting creatine with nutrients that may enhance insulin sensitivity. Co-ingestion of creatine $(\mathrm{Cr})$ with an antihyperglycemic extract of Artemisia dracunculus (Russian tarragon (RT)), has been shown to influence plasma $\mathrm{Cr}$ levels comparable to co-ingestion of $\mathrm{Cr}$ and glucose [1]. However, other research has shown that short term (5 days) co-ingestion of $\mathrm{Cr}$ and $\mathrm{RT}(\mathrm{Cr}+\mathrm{RT})$ did not enhance whole body creatine retention or muscle free creatine content [2]. The purpose of this on-going investigation was to compare the long-term effects of resistance training in combination with either $\mathrm{Cr}+\mathrm{RT}$, or $\mathrm{Cr}$ with carbohydrate $(\mathrm{Cr}+\mathrm{CHO})$, or carbohydrate (PL) ingestion.

\section{Methods}

In a randomized, double-blind manner, 12 resistance trained males $(n=8)$ and females $(n=4)$ consumed either $90 \mathrm{~g} /$ day of dextrose $+0.38 \mathrm{~g} /$ day of fruit punch flavoring $(\mathrm{PL}, \mathrm{n}=5), 84 \mathrm{~g} /$ day of dextrose $+6 \mathrm{~g} /$ day of $\mathrm{Cr}+0.38 \mathrm{~g} /$ day of fruit punch flavoring $(\mathrm{Cr}+\mathrm{CHO}, \mathrm{n}=4)$, or 1,100 $\mathrm{mg} /$ day of $\mathrm{RT}+6 \mathrm{~g} /$ day of $\mathrm{Cr}+40 \mathrm{~g} /$ day of hydrolyzed

\footnotetext{
* Correspondence: adam.parker@angelo.edu

'Department of Kinesiology, Angelo State University, San Angelo, TX 76909 USA;

Full list of author information is available at the end of the article
}

collagen $+0.38 \mathrm{~g} /$ day of fruit punch flavoring $(\mathrm{Cr}+\mathrm{RT}$, $\mathrm{n}=3$ ) for 8 weeks. Participants performed 4 days per week (2 upper-body, 2 lower-body) of resistance training. Body composition via DEXA, 1 repetition maximum (1RM) on bench press and back squat, and anaerobic power were measured at weeks 0,4 , and 8 . Delta scores for all dependent variables were analyzed using individual ANOVAs.

\section{Results}

Increases in lean body mass were significantly higher $(\mathrm{p}=0.038)$ after 4 weeks in the $\mathrm{Cr}+\mathrm{CHO}(1.56 \pm 0.64 \mathrm{~kg})$ and the $\mathrm{Cr}+\mathrm{RT}(1.87 \pm 0.98 \mathrm{~kg})$ groups compared to $\mathrm{PL}$ $(0.02 \pm 1.08 \mathrm{~kg})$. There were no other significant effects due to supplementation on body composition, 1RM bench press, 1RM back squat, or anaerobic power. Additionally, the $\mathrm{Cr}+\mathrm{RT}$ group showed average improvements in strength to be equal to or greater than $\mathrm{Cr}+\mathrm{CHO}$. Also, by the end of the study, body fat decreased in the $\mathrm{Cr}+\mathrm{RT}$ group $(-2.42 \pm 6.81 \mathrm{~kg})$, while the other two groups showed increases in body fat $(\mathrm{Cr}+\mathrm{CHO} 0.83 \pm 0.79 \mathrm{~kg}$, PL $1.10 \pm 0.88 \mathrm{~kg}$ ), potentially linked to the increased caloric load.

\section{Conclusion}

Although there was a limited sample size for each supplement group, preliminary data suggests that consuming $\mathrm{Cr}+\mathrm{RT}$ is as effective as consuming $\mathrm{Cr}+\mathrm{CHO}$ in regards to gains in LBM and strength over the course of 8 weeks of resistance training. 


\section{Acknowledgements}

Supported by Athletic Edge Nutrition.

\section{Authors' details}

'Department of Kinesiology, Angelo State University, San Angelo, TX 76909,

USA: ${ }^{2}$ Increnovo LLC, 2138 E Lafayette PI, Milwaukee, WI 53202, USA.

Published: 6 December 2013

\section{References}

1. Jäger R, Kendrick IP, Purpura M, Harris RC, Ribnicky DM, Pischel I: The effect of Russian Tarragon (artemisia dracunculus L.) on the plasma creatine concentration with creatine monohydrate administration. J Int Soc Sports Nutr 2008, 5(Suppl 1):P4.

2. Oliver JM, Jagim AR, Sanchez A, Kelley K, Galvan E, Fluckey J, Riechman S, Greenwood M, Jäger R, Purpura M, Pischel I, Kreider RB: Effects of shortterm ingestion of Russian Tarragon prior to creatine monohydrate supplementation on whole body and muscle creatine retention: a preliminary investigation. J Int Soc Sports Nutr 2012, 9(Suppl 1):P24.

doi:10.1186/1550-2783-10-S1-P21

Cite this article as: Parker et al:: The effects of creatine supplementation with and without an Extract of Artemisia dracunculus on resistance training adaptations: preliminary findings. Journal of the International Society of Sports Nutrition 2013 10(Suppl 1):P21.

\section{Submit your next manuscript to BioMed Central} and take full advantage of:

- Convenient online submission

- Thorough peer review

- No space constraints or color figure charges

- Immediate publication on acceptance

- Inclusion in PubMed, CAS, Scopus and Google Scholar

- Research which is freely available for redistribution

Submit your manuscript at www.biomedcentral.com/submit 